\title{
PENGUKURAN EFISIENSI ORGANISASI PENGELOLA ZAKAT DENGAN METODE DATA ENVELOPMENT ANALYSIS
}

\author{
Aulia Zahra, Prayogo P. Harto \& Ahmad Bisyri AS \\ Program Studi Akuntansi Syariah \\ Sekolah Tinggi Ekonomi Islam SEBI \\ Email: auliazahra1994@gmail.com
}

\begin{abstract}
This study aims to determine the level of efficiency of Zakat Management Organization period 2012-2014 using Data Envelopment Analysis (DEA) method with the production approach. Data Envelopment Analysis (DEA) is a non-parametric method used to measure the efficiency level of Decision Making Units (DMU). This method measures the ratio between output and input which are compared between the studied Zakat Management Organization. Output variables used are fund collected and channeled fund. While input variables used are personnel costs, socialization costs, and other operational costs. The results of this study show that the efficiency of Zakat Management Organization in the year 2013 is still better than in 2012 and 2014, both technically $(93,50 \%)$, scale $(73,28 \%)$, and overall $(70,54 \%)$. Calculation of 7 Zakat Management Organization in 2013 with the assumption of Constant Return to Scale (CRS), shows only 3 Zakat Management Organization efficient, that is YBM BRI, BSM Ummat, and BAMUIS BNI. The main cause of inefficiency from the output oriented measures is channeled fund and fund collected, which is equal $49,23 \%$ and $48,13 \%$. While the input oriented measures states that the source of inefficiency is the personnel costs $(33,42 \%)$, the socialization costs $(33,72 \%)$, and the cost of other operational $(32,29 \%)$.
\end{abstract}

Keywords : Efficiency, Zakat Management Organization, Data Envelopment Analysis.

\section{PENDAHULUAN}

Dalam sistem ekonomi Islam, zakat merupakan suatu instrumen strategis yang mempengaruhi tingkah laku seorang muslim, masyarakat, dan pembangunan ekonomi pada umumnya. Zakat adalah salah satu rukun Islam yang merupakan kewajiban yang dibebankan atas harta kekayaan seorang muslim menurut aturan tertentu. Menurut Beik dan Tanjung (2011), zakat dipandang sebagai instrumen ekonomi yang berperan sebagai stimulus bagi terciptanya pertumbuhan ekonomi yang berkeadilan, sehingga upaya pengentasan kemiskinan dan kesenjangan pendapatan dapat berjalan lebih optimal (hal. 7).

Keberadaan zakat secara ekonomi dapat menghapus tingkat perbedaan yang mencolok antara si fakir dan si kaya. Zakat juga sebagai alternatif instrumen kebijakan fiskal untuk mewujudkan pemerataan pendapatan diantara umat Islam (Nasution \& Mintarti, 2009, hal. 1). Melalui zakat, 
berbagai problem masyarakat baik sosial maupun ekonomi seperti kebodohan dan kemiskinan dapat teratasi (Laela, 2010). Oleh karena itu, pengelolaan zakat yang tepat dapat menciptakan tata ekonomi yang adil dan sejahtera. Berikut ini adalah grafik terkait tingkat kemiskinan dan ketidakadilan distribusi pendapatan di Indonesia.

Grafik 1. Statistik Kemiskinan dan Ketidaksetaraan di Indonesia

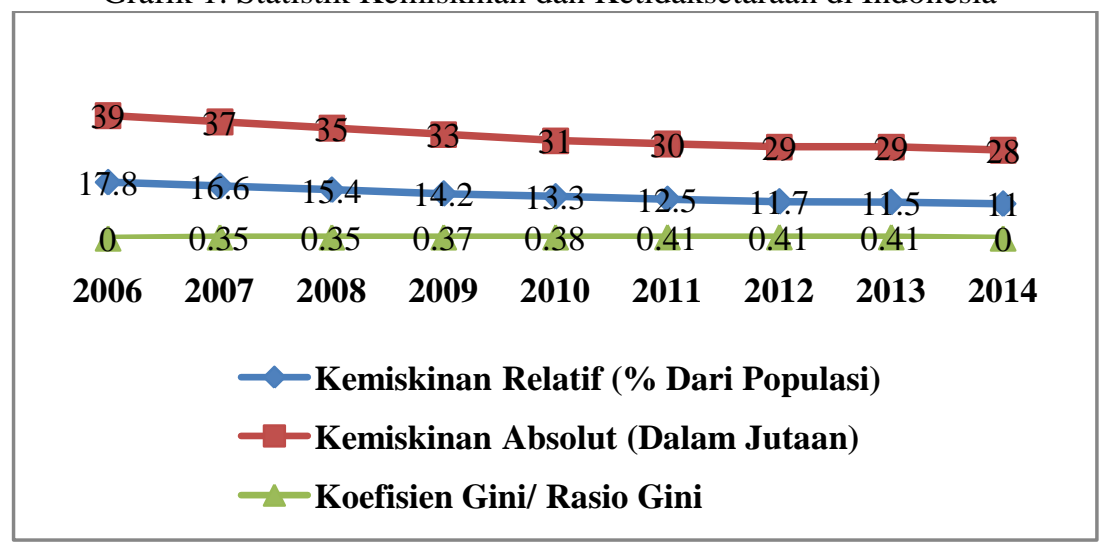

Sumber : (Indonesia Investments, 2015)

Berdasarkan grafik 1 terlihat bahwa koefisien gini atau ketidakadilan distribusi pendapatan di Indonesia dari tahun ke tahun terus mengalami peningkatan. Mulai dari tahun 2010 yang hanya berkisar 0,38, kemudian di tahun 2011 meningkat menjadi sebesar 0,41, dan sampai dengan tahun 2014 mengalami kestabilan di angka 0,41. Tentu saja hal ini menjadi sebuah hal yang patut dicermati mengingat potensi zakat yang ada di Indonesia harusnya dapat menciptakan keadilan distibusi kekayaan masyarakat.

Potensi zakat yang menurut Didin Hafidhuddin mencapai Rp. 210 triliun per tahun, nyatanya baru terkumpul Rp. 1,7 triliun di tahun 2011 (Mintarti \& Beik, 2012, hal. 89). Bahkan potensi zakat yang diperkirakan sampai dengan saat ini harusnya mencapai Rp. 217 triliun (Republika Online, 2015). Namun berdasarkan database yang dimiliki Badan Amil Zakat Nasional (BAZNAS), jumlah dana zakat yang berhasil terkumpul di tahun 2013 hanya sebesar Rp. 50 miliar (BAZNAS, 2015). Ini artinya masih tersimpan potensi besar zakat di masyarakat yang apabila terhimpun dengan baik, dapat mengurangi angka kemiskinan di Indonesia.

Berdasarkan pemaparan di atas dapat disimpulkan bahwa potensi zakat di Indonesia sangat besar dan diyakini dapat menciptakan keadilan distribusi kekayaan masyarakat. Namun, dana zakat yang berhasil dikumpulkan masih jauh dari potensi yang ada. Hal ini menunjukkan belum optimalnya pengelolaan zakat, baik dari segi penghimpunan maupun pendistribusian. Sehingga realitasnya menunjukkan bahwa antara potensi zakat dan realisasi penghimpunan zakat masih terdapat gap yang jauh. Berikut ini adalah grafik 2 terkait jumlah penghimpunan dana zakat di Indonesia yang berhasil dikumpulkan oleh Lembaga Amil Zakat Nasional. 
Grafik 2. Jumlah Penghimpunan Dana Zakat di Indonesia

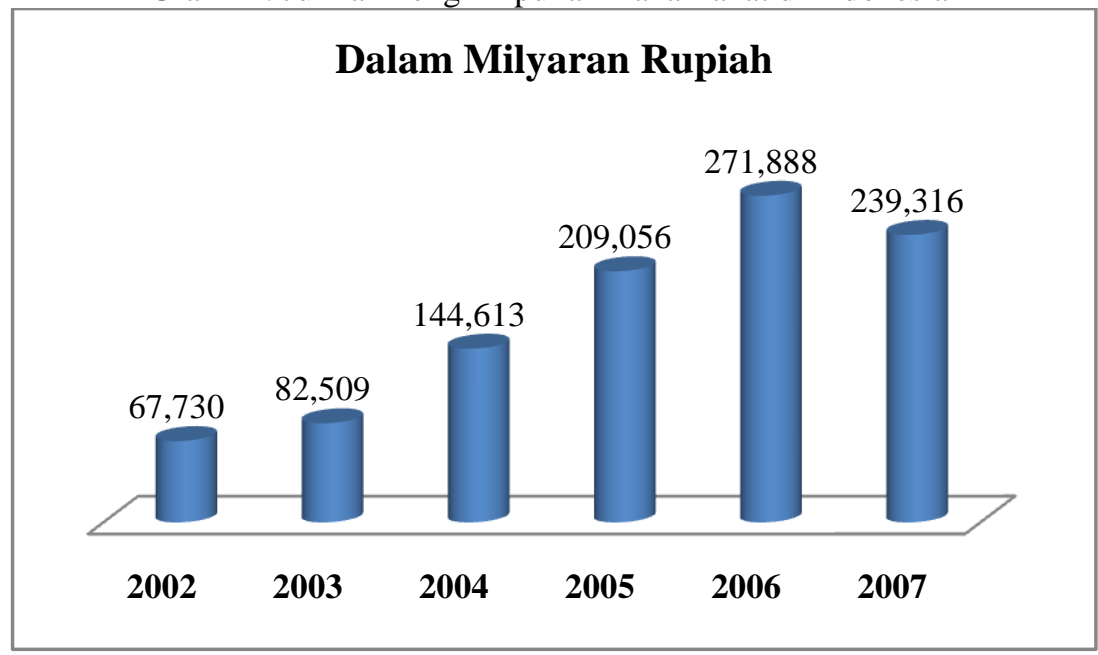

Sumber : (Nasution \& Mintarti, 2009, hal. 18)

Maraknya pertumbuhan Organisasi Pengelola Zakat (OPZ) di Indonesia akhir-akhir ini bisa jadi sebuah indikasi positif. Namun yang harus digaris bawahi bahwa syarat utama mendirikan Organisasi Pengelola Zakat (OPZ) adalah amanah dan profesional (Mintarti \& Beik, 2012, hal. 89). Maraknya pertumbuhan Organisasi Pengelola Zakat (OPZ) di Indonesia dapat dilihat pada grafik 3 di bawah ini.

Grafik 3. Pertumbuhan Organisasi Pengelola Zakat di Indonesia

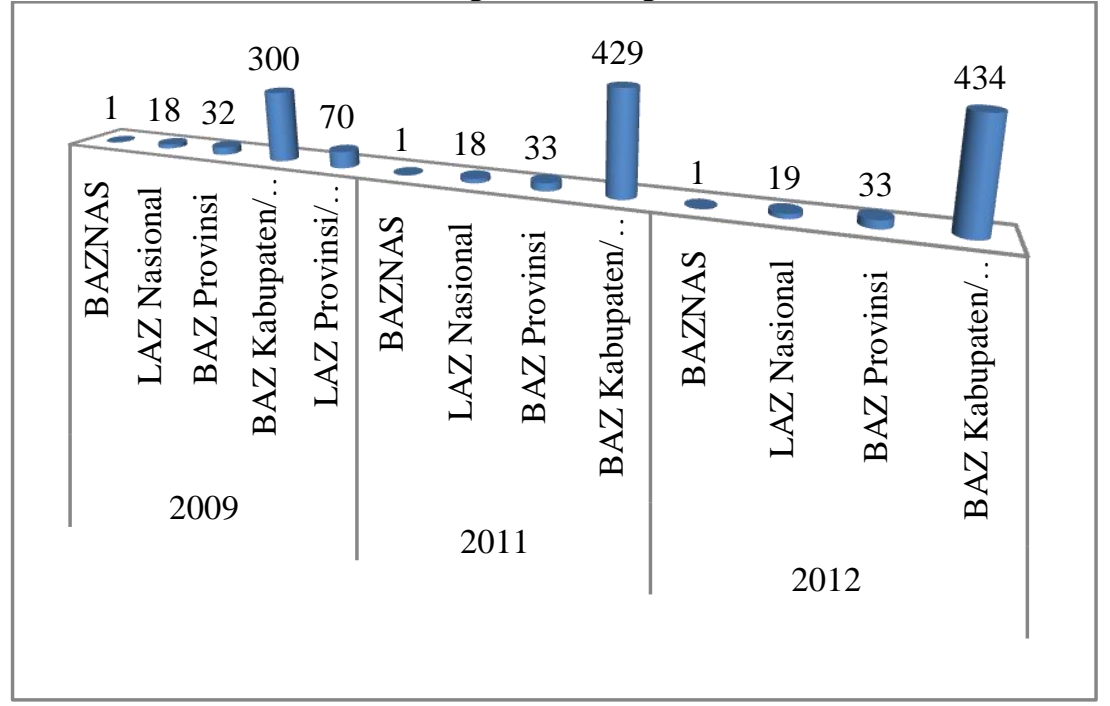

Sumber : (Mubarok \& Fanani, 2014) 
Berdasarkan grafik 3 terlihat bahwa pertumbuhan Organisasi Pengelola Zakat (OPZ) di Indonesia dari tahun ke tahun terus mengalami peningkatan. Pada tahun 2009 Forum Organisasi Zakat (FOZ) mencatat ada 421 Organisasi Pengelola Zakat (OPZ) di Indonesia. Kemudian di tahun 2011 meningkat menjadi 481 Organisasi Pengelola Zakat (OPZ) yang tercatat di Indonesia. Dan di tahun 2012 juga mengalami peningkatan sehingga menjadi 487 Organisasi Pengelola Zakat (OPZ) yang tercatat di Indonesia.

Sampai dengan tahun 2012 sudah ada 19 Organisasi Pengelola Zakat (OPZ) nasional yang memiliki izin resmi dari pemerintah. Namun jika dikaitkan antara potensi dan realisasi penghimpunan dana zakat yang dilakukan oleh berbagai Organisasi Pengelola Zakat (OPZ) tersebut tidaklah sebanding. Menurut Akbar (2009), hal ini menjadi tantangan tersendiri bagi Organisasi Pengelola Zakat (OPZ) untuk meningkatkan kinerjanya, sehingga dapat menghimpun dan menyalurkan dana zakat dengan optimal. Oleh karena itu, dibutuhkan optimalisasi potensi zakat salah satunya dengan efisiensi.

Hal ini merupakan tuntutan yang sesuai dengan Undang-Undang Nomor 23 Tahun 2011 Tentang Pengelolaan Zakat, dalam pasal 3 menyebutkan bahwa salah satu tujuan pengelolaan zakat adalah meningkatkan efisiensi pelayanan dalam pengelolaan zakat (UndangUndang, 2011). Dalam hal ini pun Qardhawi (2005) menegaskan perlunya efisiensi operasional amilin. Sehingga dapat dikatakan bahwa efisiensi itu mutlak diperlukan bagi suatu Organisasi Pengelola Zakat (OPZ) dalam pengelolaan zakatnya.

Dalam menjalankan tugasnya, Organisasi Pengelola Zakat (OPZ) membutuhkan dana operasional yang tidak kecil, mulai dari gaji amilin, biaya sosialisasi, sampai dengan biaya operasional lainnya. Menurut Akbar (2009), Organisasi Pengelola Zakat (OPZ) adalah organisasi yang bersifat nirlaba. Seluruh biaya operasional diambil dari dana zakat yang terhimpun oleh Organisasi Pengelola Zakat (OPZ) tersebut. Dana yang tidak terkelola dengan baik sering kali menjadi pemborosan dalam biaya yang seharusnya bisa ditekan, sehingga dibutuhkan sebuah efisiensi bagi Organisasi Pengelola Zakat (OPZ).

Dalam beberapa tahun terakhir, penelitian mengenai efisiensi Organisasi Pengelola Zakat (OPZ) dengan menggunakan metode Data Envelopment Analysis (DEA) semakin banyak diterapkan. Menurut penelitian yang dilakukan oleh Akbar (2009), mengenai analisis efisiensi Organisasi Pengelola Zakat (OPZ) nasional dengan pendekatan Data Envelopment Analysis (DEA), yaitu mengukur rasio antara output dan input yang diperbandingkan antar 9 Organisasi Pengelola Zakat (OPZ) nasional yang diteliti. Hasil dari penelitian ini menunjukkan bahwa efisiensi Organisasi Pengelola Zakat (OPZ) tahun sebelumnya lebih baik dari tahun sesudahnya, baik itu secara teknis, skala, dan overall.

Kemudian menurut penelitian yang dilakukan oleh Wahab dan Rahman (2012), mengenai efisiensi Organisasi Pengelola Zakat (OPZ) di Malaysia dengan pendekatan Data Envelopment Analysis (DEA), yaitu mengukur rasio antara output dan input yang diperbandingkan untuk 
memperkirakan efisiensi zakat dan menentukan efisiensi Organisasi Pengelola Zakat (OPZ) di Malaysia. Hasil dari penelitian ini menunjukkan bahwa inefisiensi teknis murni dan inefisiensi skala telah mengakibatkan inefisiensi Organisasi Pengelola Zakat (OPZ).

Penelitian lainnya yang dilakukan oleh Cahyono (2015), mengenai efisiensi kinerja Badan Amil Zakat Nasional (BAZNAS) di Indonesia dengan pendekatan Data Envelopment Analysis (DEA), yaitu mengukur rasio antara output dan input yang diperbandingkan antar tahun yang diteliti. Hasil dari penelitian ini menunjukkan bahwa dari periode tahun yang diteliti Badan Amil Zakat Nasional (BAZNAS) berfluktuasi dalam efisiensi kinerjanya.

Menurut Laela (2010), efisiensi Organisasi Pengelola Zakat (OPZ) menjadi perhatian utama para donatur yang akan membayarkan zakatnya. Beberapa penelitian dalam Laela (2010) menyimpulkan bahwa efisiensi lembaga donasi merupakan salah satu faktor utama yang mempengaruhi keputusan donasi para donatur. Maka dari pemaparan di atas dapat disimpulkan bahwa efisiensi itu mutlak diperlukan bagi Organisasi Pengelola Zakat (OPZ) guna mewujudkan maslahat yang lebih besar bagi umat. Sehingga harta zakat bisa dimaksimalkan untuk meningkatkan kesejahteraan masyarakat (Akbar, 2009).

Kemudian yang membedakan penelitian ini dengan penelitian sebelumnya adalah objek dan tahun yang diteliti, dimana nilai efisiensi tahun sebelumnya bersifat relatif (tidak absolut), sehingga perlu dilakukan penelitian kembali untuk melihat perkembangan efisiensi. Organisasi Pengelola Zakat (OPZ) yang menjadi objek penelitian ini diambil dengan teknik purposive sampling. Dari 19 Organisasi Pengelola Zakat (OPZ) yang telah memiliki izin resmi dari pemerintah, terpilih 7 Organisasi Pengelola Zakat (OPZ) tingkat nasional, yaitu Rumah Zakat Indonesia (RZ), Baitul Maal Ummat Islam Bank Negara Indonesia (BAMUIS BNI), Bangun Sejahtera Mitra Ummat (BSM Ummat), Baitul Maal Hidayatullah (BMH), Badan Amil Zakat Nasional (BAZNAS), LAZIS Nadhlatul Ulama (LAZISNU), Yayasan Baitul Maal Bank Rakyat Indonesia (YBM BRI).

Pemilihan 7 Organisasi Pengelola Zakat (OPZ) tersebut didasarkan pada dua hal, yaitu memiliki laporan keuangan tahun 2012-2014 yang terpublikasi, dan memiliki kesamaan variabel input dan output yang digunakan karena metode Data Envelopment Analysis (DEA) mensyaratkan demikian. Keterbatasan data yang diperoleh penulis disebabkan karena masih banyaknya Organisasi Pengelola Zakat (OPZ) yang belum mempublikasikan laporan keuangannya secara lengkap di website dan beberapa Organisasi Pengelola Zakat (OPZ) yang enggan memberikan laporan keuangannya.

\section{LANDASAN TEORI}

\subsection{EFISIENSI}

Menurut Hansen dan Mowen (2001), efisiensi adalah penggunaan input yang lebih sedikit untuk memproduksi output yang sama, atau dengan 
memproduksi lebih banyak output dengan menggunakan input yang sama, atau lebih banyak output dengan relatif lebih sedikit input (hal. 1010). Menurut Mardiasmo (2009), efisiensi diukur dengan rasio antara output dengan input. Semakin besar output dibanding input, maka semakin tinggi tingkat efisiensi suatu organisasi (hal. 133).

Menurut Nordiawan dan Hertianti (2010), efisiensi adalah hubungan antara barang dan jasa (output) yang dihasilkan sebuah kegiatan atau aktivitas dengan sumber daya (input) yang digunakan. Suatu organisasi, program, atau kegiatan dikatakan efisien apabila mampu menghasilkan output tertentu dengan input serendah-rendahnya, atau dengan input tertentu mampu menghasilkan output sebesar-besarnya (hal. 161).

Menurut Karim (2011), dalam kriteria ekonomi suatu sistem produksi dikatakan lebih efisien bila memenuhi salah satu dari kriteria ini, yaitu minimalisasi biaya untuk memproduksi jumlah yang sama, dan maksimalisasi produksi dengan jumlah biaya yang sama (hal. 118).

\subsection{EFISIENSI DALAM ISLAM}

Menurut Ali dan Ascarya (2010), tujuan efisiensi adalah untuk mencapai keuntungan yang optimal. Dalam Islam, perwujudan keuntungan yang optimal dihasilkan melalui kerja keras atau usaha yang optimal untuk menghasilkan sesuatu secara optimal dengan tetap menjaga keseimbangan dan etika syariah. Keuntungan yang dihasilkan harus seimbang dengan kerja keras dan beban yang dikeluarkan. Rasulullah SAW. bersabda :

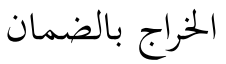

"Setiap keuntungan yang didapatkan harus sesuai dengan beban yang dikeluarkan.” (HR. Tirmidzi, No. 1285).

Menurut Ali dan Ascarya (2010), untuk mewujudkan optimalisasi dan keseimbangan, Islam memberikan beberapa tuntunan, diantaranya :

1. Memanfaatkan Seluruh Potensi Sumber Daya Alam

Allah SWT. telah menganjurkan kepada manusia agar senantiasa bekerja memakmurkan bumi dan memanfaatkan seluruh potensi sumber daya alam yang ada di bumi untuk kebutuhan manusia. Allah SWT. berfirman:

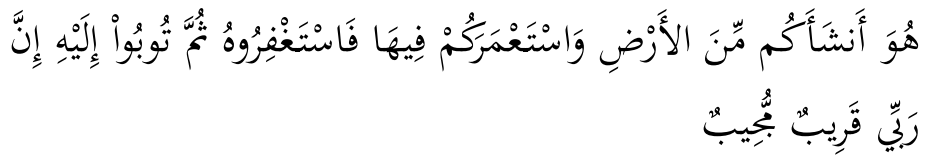

“... Dia telah menciptakan kamu dari bumi (tanah) dan menjadikan kamu pemakmurnya, karena itu mohonlah ampunan-Nya, kemudian bertobatlah kepada-Nya. Sesungguhnya Tuhanku amat dekat (rahmatNya) lagi memperkenankan (doa hamba-Nya)." (QS. Huud [11] : 61).

2. Spesialisasi Kerja 
Pembagian tenaga kerja akan lebih tergantung pada perbedaan keahlian dan keterampilan penduduk. Dalam Islam, prinsip dasar tentang spesialisasi dapat ditelaah dalam hadits Rasulullah SAW. yang menjelaskan tentang konsep itqan dan ihsan. Mengenai itqan Rasulullah SAW. bersabda :

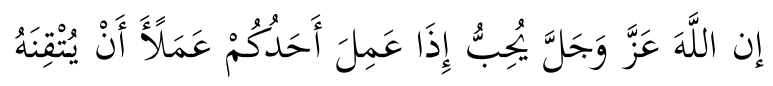

"Sesungguhnya Allah mencintai jika seseorang melakukan pekerjaan (berproduksi) dengan cermat dan tekun (itqan).” (HR. Thabrani, No. 897).

3. Larangan Terhadap Riba

Salah satu cara Islam mewujudkan efisiensi dengan cara meminimalisasi biaya produksi adalah dengan pengharaman riba atau bunga. Sebagai bagian dari elemen biaya tetap dalam produksi, penghapusan bunga akan membuat biaya produksi lebih rendah atau efisien. Allah SWT. berfirman:

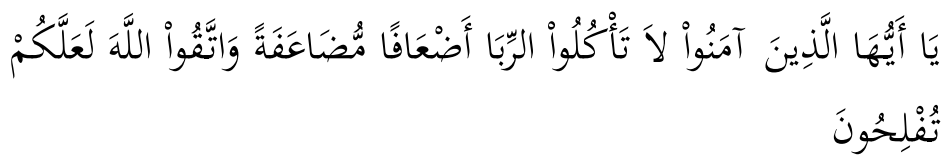

"Hai orang-orang yang beriman, janganlah kamu memakan riba dengan berlipat ganda dan bertakwalah kamu kepada Allah supaya kamu mendapat keberuntungan." (QS. Ali-Imran [3] : 130).

4. Larangan Israf dan Tabdzir Dalam Produksi

Menurut Kantakji (2003) dalam Ali dan Ascarya (2010), israf adalah kesalahan menggunakan takaran yang tepat, sedangkan tabdzir adalah kebodohan dalam menggunakan alokasi yang tepat. Allah SWT. berfirman :

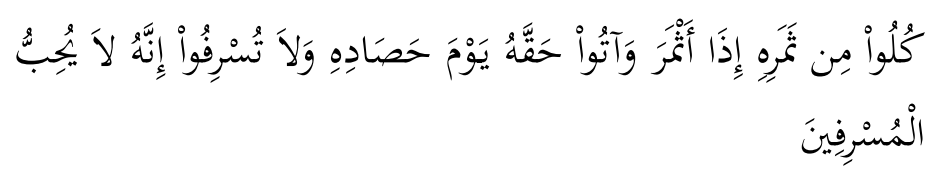

“... Makanlah dari buahnya (yang bermacam-macam itu) bila dia berbuah, dan tunaikanlah haknya di hari memetik hasilnya (dengan disedekahkan kepada fakir miskin), dan janganlah kamu berlebihlebihan. Sesungguhnya Allah tidak menyukai orang yang berlebihlebihan." (QS. Al-An'am [6] : 141).

\subsection{EFISIENSI DALAM ORGANISASI PENGELOLA ZAKAT}

Menurut Akbar (2009), Organisasi Pengelola Zakat (OPZ) merupakan organisasi yang bertindak sebagai amil zakat. Dalam menjalankan tugasnya 
tersebut, Organisasi Pengelola Zakat (OPZ) membutuhkan dana operasional yang tidak kecil, mulai dari gaji amilin, biaya sosialisasi, dan biaya operasional lainnya. Amilin itu adalah pegawai dalam suatu Organisasi Pengelola Zakat (OPZ), maka hendaklah ia diberi upah sesuai dengan pekerjaannya, namun upah yang diberikan pun tidak terlalu kecil dan tidak juga berlebihan.

Pendapat Ibnu Qasim dalam kitab Al-Majmuu' Syarah Al-Muhadzzab yang menerangkan mengenai distribusi zakat kepada amil sebagai berikut :

"Apabila yang melakukan distribusi zakat adalah Imam (pemerintah) maka harus dibagi kepada delapan golongan penerima zakat. Bagian pertama adalah untuk amil, karena amil mengambil bagian harta zakat sebagai upah, sementara golongan lainnya sebagai dana sosial. Apabila bagian amil sesuai dengan kewajaran sebagai upah pengelola zakat, maka akan diberikan kepadanya bagian tersebut. Jika terjadi defisit anggaran, dimana bagian amil lebih kecil dari kewajaran upah pengelola zakat maka akan ditambahkan. Ditambahan dari mana? Imam Syafi'i berpendapat: "Ditambahkan dengan diambil dari bagian kemashlahatan (fi sabilillah)". Sekiranya ada yang berpendapat bahwa bagiannya dilengkapi dari bagian golongan-golongan mustahik yang lain maka pendapat tersebut tidak salah". (Majelis Ulama Indonesia, 2011).

Menurut riwayat dari Imam Syafi'i, disebutkan bahwa amilin diberi zakat sama seperti bagian mustahik lain, yakni sebesar 12,5\%, karena didasarkan pada pendapatnya yang menyamakan hak bagi seluruh golongan mustahik sebesar seperdelapan dari total zakat yang terkumpul. Apabila upah itu lebih besar dari bagian tersebut, maka harus diambil dari harta di luar zakat (Qardhawi, 2007, hal. 556).

Sedangkan menurut Jumhur Ulama, pendistribusian harta tidak harus dilakukan secara merata kepada delapan ashnaf mustahik zakat. Ibnu Katsir dalam tafsirnya terhadap surah At-Taubah ayat 60 (Akbar, 2009).

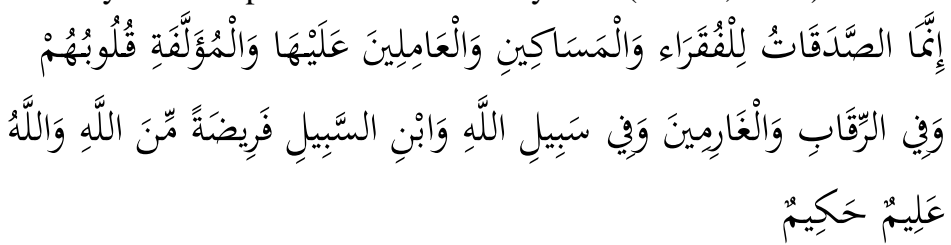

"Sesungguhnya zakat-zakat itu, hanyalah untuk orang-orang fakir, orangorang miskin, pengurus-pengurus zakat, para muallaf yang dibujuk hatinya, untuk (memerdekakan) budak, orang-orang yang berhutang, untuk jalan Allah dan untuk mereka yang sedang dalam perjalanan, sebagai suatu ketetapan yang diwajibkan Allah, dan Allah Maha Mengetahui lagi Maha Bijaksana.” (QS. At-Taubah [9] : 60).

Beliau menuturkan bahwa pendapat yang paling sahih, dan Allah Maha Mengetahui, tidaklah wajib memberikan kepada semua golongan, namun cukup menyerahkan kepada salah satu dari delapan golongan itu dan 
seluruh zakat dapat diberikan kepadanya, walaupun masih terdapat golongan yang lain.

Kemudian Imam Malik dan sekelompok ulama salaf dan khalaf berpendapat bahwa penyebutan delapan golongan tersebut untuk menjelaskan pihak penerima, bukan untuk menyatakan kewajiban menghabiskan dana zakat untuk semua golongan.

Imam Malik berkata, "Hendaklah ia (amil) berijtihad dan menyelidiki golongan yang amat membutuhkan dan mendahulukan mereka, kemudian yang di bawah mereka, dan seterusnya, yakni orang-orang yang malang yang tidak memiliki apa-apa. Jika dilihat kemalangan itu lebih banyak dijumpai adalah golongan orang-orang miskin, hendaklah pada tahun itu mereka didahulukan. Jika pada tahun berikutnya kemalangan itu diderita oleh orangorang yang dalam perjalanan, hendaklah dialihkan kepada mereka".

Jadi, kadar zakat yang hendaknya diterima Organisasi Pengelola Zakat (OPZ) adalah kadar yang secukupnya, tidak terlalu kecil dan tidak juga berlebihan. Tidak ada ketentuan yang menetapkan kadar 12,5\% dari total zakat, tetapi disesuaikan dengan kadar kebutuhan dan kadar kepentingan. Namun, kita mengambil pendapat Imam Syafi'i dalam menentukan bagian maksimal untuk diberikan kepada para petugas zakat, yakni ukurannya tidak lebih dari $12,5 \%$ atau seperdelapan, baik yang bertugas dalam menghimpun maupun yang mendistribusikannya (Qardhawi, 2005).

Atas dasar inilah diperlukan suatu usaha untuk mengefisienkan biaya operasional Organisasi Pengelola Zakat (OPZ) sesuai dengan tingkat kebutuhan dan tingkat kepentingannya. Sehingga biaya yang dikeluarkan sesuai dengan kebutuhan dan kepentingan Organisasi Pengelola Zakat (OPZ). Dengan demikian harta zakat bisa dimaksimalkan demi tercapainya tujuan zakat, yakni meningkatkan kesejahteraan masyarakat dan mengurangi kemiskinan.

\subsection{PENELITIAN TERDAHULU}

Dalam beberapa tahun terakhir, penelitian mengenai efisiensi Organisasi Pengelola Zakat (OPZ) dengan menggunakan metode Data Envelopment Analysis (DEA) semakin banyak diterapkan. Pada tabel 2.1 berikut ini akan dipaparkan secara singkat beberapa studi empiris yang membahas mengenai efisiensi pada Organisasi Pengelola Zakat (OPZ) dengan metode Data Envelopment Analysis (DEA).

Tabel 1. Penelitian Terdahulu

\begin{tabular}{llll}
\hline No & \multicolumn{2}{c}{$\begin{array}{c}\text { Judul, Penulis, dan } \\
\text { Tahun }\end{array}$} & \multicolumn{2}{c}{ Metode dan Variabel } & \multicolumn{1}{c}{ Hasil } \\
\hline 1 & Analisis $\quad$ Efisiensi & Metode : & $\begin{array}{l}\text { Menunjukkan bahwa } \\
\text { efisiensi Organisasi }\end{array}$ \\
& $\begin{array}{l}\text { Organisasi Pengelola } \\
\text { Zakat (OPZ) Nasional } \\
\text { Dengan Pendekatan }\end{array}$ & $\begin{array}{l}\text { Data Envelopment } \\
\text { Analysis (DEA). }\end{array}$ & $\begin{array}{l}\text { Pengelola Zakat } \\
\text { (OPZ) tahun }\end{array}$ \\
& & & \\
\hline
\end{tabular}




\begin{tabular}{|c|c|c|c|}
\hline & $\begin{array}{lr}\text { Datar } & \text { Envelopment } \\
\text { Analysis, } & \text { Nasher } \\
\text { Akbar, 2009. } & \end{array}$ & $\begin{array}{l}\text { Biaya personalia, } \\
\text { biaya sosialisasi, dan } \\
\text { biaya operasional } \\
\text { lainnya. } \\
\text { Variabel } \text { Output: } \\
\text { Dana terhimpun dan } \\
\text { dana tersalurkan. }\end{array}$ & $\begin{array}{l}\text { sebelumnya lebih } \\
\text { baik dari pada tahun } \\
\text { berikutnya. }\end{array}$ \\
\hline 2 & $\begin{array}{lr}\text { Efficiency of } & \text { Zakat } \\
\text { Institutions } & \text { in } \\
\text { Malaysia: } & \text { An } \\
\text { Application of Data } \\
\text { Envelopment } \\
\text { Analysis, Norazlina } \\
\text { Abd. Wahab dan } \\
\text { Abdul Rahim Abdul } \\
\text { Rahman, 2012. }\end{array}$ & $\begin{array}{l}\text { Metode : } \\
\text { Data Envelopment } \\
\text { Analysis (DEA). } \\
\text { Variabel Input : } \\
\text { Jumlah staf dan total } \\
\text { pengeluaran. } \\
\text { Variabel Output: } \\
\text { Total koleksi, total } \\
\text { distribusi, dan jumlah } \\
\text { pembayar zakat. }\end{array}$ & $\begin{array}{l}\text { Menunjukkan bahwa } \\
\text { inefisiensi teknis } \\
\text { murni dan inefisiensi } \\
\text { skala telah } \\
\text { mengakibatkan } \\
\text { inefisiensi lembaga } \\
\text { zakat. }\end{array}$ \\
\hline 3 & $\begin{array}{l}\text { The Efficiency of } \\
\text { Zakat Collection and } \\
\text { Distribution: } \\
\text { Evidence from Two } \\
\text { Stage Analysis, Ismail } \\
\text { HJ. Ahmad dan } \\
\text { Masturah Ma'in, } \\
\text { 2014. }\end{array}$ & $\begin{array}{l}\text { Metode : } \\
\text { Data Envelopment } \\
\text { Analysis (DEA) dan } \\
\text { Model Tobit. } \\
\text { Variabel Input: } \\
\text { Jumlah amil, jumlah } \\
\text { cabang, jumlah agen, } \\
\text { dan beban distribusi. } \\
\text { Variabel Output: } \\
\text { Zakat koleksi dan } \\
\text { distribusi zakat. }\end{array}$ & $\begin{array}{l}\text { Menunjukkan bahwa } \\
\text { pengumpulan dan } \\
\text { distribusi memiliki } \\
\text { sumber daya lagging } \\
\text { yang disebut teknis } \\
\text { efisiensi. Kemudian } \\
\text { efisiensi keseluruhan, } \\
\text { alokatif, dan biaya } \\
\text { skor efisiensi } \\
\text { menunjukkan } \\
\text { efisiensi maksimum } \\
\text { dicapai hampir setiap } \\
\text { tahun. }\end{array}$ \\
\hline 4 & $\begin{array}{l}\text { Efficiency of Islamic } \\
\text { Institutions: } \\
\text { Empirical Evidence of } \\
\text { Zakat Organizations, } \\
\text { Performance in } \\
\text { Malaysia, Abd Halim } \\
\text { Mohd Noor, 2015. }\end{array}$ & $\begin{array}{l}\text { Metode : } \\
\text { Ikaz Model Zakat } \\
\text { Index. } \\
\text { Variabel : } \\
\text { Input, process, output, } \\
\text { outcomes. }\end{array}$ & $\begin{array}{l}\text { Menunjukkan bahwa } \\
\text { adanya sumber daya } \\
\text { yang memadai atau } \\
\text { masukan yang } \\
\text { tersedia untuk } \\
\text { organisasi. }\end{array}$ \\
\hline 5 & $\begin{array}{l}\text { Efficiency of BAZNAS } \\
\text { (Indonesian National } \\
\text { Zakat Amil Agency) } \\
\text { Performance, Eko }\end{array}$ & $\begin{array}{l}\text { Metode: } \\
\text { Data Envelopment } \\
\text { Analysis (DEA). } \\
\text { Variabel Input: }\end{array}$ & $\begin{array}{l}\text { Menunjukkan bahwa } \\
\text { Badan Amil Zakat } \\
\text { Nasional (BAZNAS) } \\
\text { berfluktuasi dalam }\end{array}$ \\
\hline
\end{tabular}


Tabel 3. Variabel Input dan Output Pendekatan Produksi

\begin{tabular}{llll}
\hline Variabel Input & \multicolumn{1}{c}{ Definisi } & \multicolumn{3}{c}{ Sumber Data } \\
\hline Input 1 (X1) & Biaya Personalia & $\begin{array}{l}\text { Laporan } \\
\text { Amil }\end{array}$ & Perubahan Dana \\
\hline Input 2 (X2) & Biaya Sosialisasi & $\begin{array}{l}\text { Laporan } \\
\text { Amil }\end{array}$ & Perubahan Dana \\
\hline Input 3 (X3) & Biaya Operasional Lainnya & $\begin{array}{l}\text { Laporan } \\
\text { Amil }\end{array}$ & Perubahan Dana \\
\hline Variabel Output & Definisi & \multicolumn{2}{c}{ Sumber Data } \\
\hline Output 1 (Y1) & Dana Terhimpun & Laporan Perubahan Dana \\
\hline Output 2 (Y2) & Dana Tersalurkan & Laporan Perubahan Dana \\
\hline & Sumber : Data diolah dari penelitian terdahulu, (2015)
\end{tabular}

\section{PEMBAHASAN}

Total Decision Making Unit (DMU) yang dianalisis berjumlah 16 dari 7 Organisasi Pengelola Zakat (OPZ) yang diperbandingkan tingkat efisiensinya. Berikut ini tabel 4 terkait rata-rata dari data variabel input dan output yang digunakan.

Tabel 4. Rata-Rata Variabel Input dan Output Organisasi Pengelola Zakat (dalam ribuan)

\begin{tabular}{lccccc}
\hline \multirow{2}{*}{ Variabel } & 2012 & \multicolumn{2}{c}{2013} & \multicolumn{2}{c}{2014} \\
\cline { 2 - 6 } & Angka & Angka & $\begin{array}{c}\text { Growt } \\
h\end{array}$ & Angka & $\begin{array}{c}\text { Grow } \\
\text { th }\end{array}$ \\
\hline $\begin{array}{l}\text { Dana Terhimpun } \\
\text { (Y1) }\end{array}$ & 67.417 .781 & 60.643 .069 & $-10 \%$ & 92.859 .011 & $53 \%$ \\
\hline $\begin{array}{l}\text { Dana Tersalurkan } \\
\text { (Y2) }\end{array}$ & 54.589 .986 & 52.936 .104 & $-3 \%$ & 75.309 .979 & $42 \%$ \\
\hline $\begin{array}{l}\text { Biaya Personalia } \\
(X 1)\end{array}$ & 6.655 .056 & 5.804 .847 & $-13 \%$ & 9.102 .315 & $57 \%$ \\
\hline $\begin{array}{l}\text { Biaya Sosialisasi } \\
(X 2)\end{array}$ & 1.939 .347 & 1.944 .281 & $0,3 \%$ & 2.260 .737 & $16 \%$ \\
\hline $\begin{array}{l}\text { Biaya Operasional } \\
\text { Lainnya (X3) }\end{array}$ & 4.213 .125 & 4.354 .455 & $3 \%$ & 7.631 .095 & $75 \%$ \\
\hline
\end{tabular}

Berdasarkan tabel 4, menunjukkan bahwa dana terhimpun pada tahun 2012 lebih besar dari tahun 2013. Dimana pertumbuhan dana terhimpun pada tahun 2012 ke tahun 2013 mengalami penurunan hingga 10\%. Sedangkan dana terhimpun pada tahun 2013 lebih kecil dari tahun 2014. Dimana pertumbuhan dana terhimpun dari tahun 2013 ke tahun 2014 mengalami kenaikan hingga 53\%. Pertumbuhan yang naik secara signifikan tersebut menunjukkan akan kesadaran masyarakat yang semakin meningkat untuk 
menyalurkan dana zakat, infak, dan sedekahnya melalui Organisasi Pengelola Zakat (OPZ).

Kemudian berdasarkan tabel 4 juga menunjukkan bahwa dana tersalurkan pun memperlihatkan gambaran yang sama halnya seperti dana terhimpun. Dimana dana tersalurkan pada tahun 2012 lebih besar dari tahun 2013 dengan penurunan pertumbuhan dana tersalurkan hingga $3 \%$. Sedangkan dana tersalurkan pada tahun 2013 lebih kecil jika dibandingkan dengan dana tersalurkan pada tahun 2014 dengan kenaikan pertumbuhan dana tersalurkan yang cukup signifikan hingga $42 \%$.

Sementara itu berdasarkan tabel 4, variabel input memperlihatkan kenaikan dari tahun ke tahun. Pada tahun 2013, kenaikan yang paling tinggi ditunjukkan oleh biaya operasional lainnya yang meningkat sebesar 3\% dibanding tahun 2012, kemudian diikuti peningkatan biaya sosialisasi sebesar $0,3 \%$, sedangkan biaya personalia mengalami penurunan hingga $13 \%$. Adapun pada tahun 2014, kenaikan input masih wajar, yakni sejalan dengan kenaikan dana terhimpun. Dimana biaya personalia mengalami peningkatan hingga $57 \%$, biaya sosialisasi mengalami peningkatan hingga $16 \%$, dan biaya operasional lainnya mengalami peningkatan hingga $75 \%$.

Jika kenaikan terjadi pada biaya personalia, maka ada faktor utama yang mendorong kenaikan biaya personalia tersebut, yaitu semakin tingginya harga kebutuhan pokok yang menjadi kebutuhan kesejahteraan amilin, dan sekaligus adanya penambahan jumlah amilin magang pada beberapa waktu tertentu. Disamping itu, kenaikan biaya personalia yang tidak diikuti oleh peningkatan dana terhimpun mengindikasikan adanya inefisiensi pada Organisasi Pengelola Zakat (OPZ).

\subsection{HASIL DAN ANALISIS EFISIENSI ORGANISASI PENGELOLA ZAKAT}

Penelitian ini menggunakan software Banxia Frontier Analyst 3. Pengukuran efisiensi Organisasi Pengelola Zakat (OPZ) didasarkan pada orientasi output dan input. Sebuah Organisasi Pengelola Zakat (OPZ) dikatakan efisien bila nilainya mencapai angka $100 \%$. Semakin ia menjauh dari angka $100 \%$ atau mendekati angka 0\%, maka ia semakin tidak efisien.

Tabel 5. Tingkat Efisiensi Organisasi Pengelola Zakat

\begin{tabular}{lcccc}
\hline Nama Unit & $\begin{array}{c}\text { CRS } \\
\text { (Overall } \\
\text { Technical } \\
\text { Efficiency) }\end{array}$ & $\begin{array}{c}\text { VRS } \\
\text { (Pure Technical } \\
\text { Efficiency) }\end{array}$ & $\begin{array}{c}\text { SKALA } \\
\text { (Scale } \\
\text { Efficiency } \\
\text { ) }\end{array}$ & $\begin{array}{c}\text { RTS } \\
\text { (Return } \\
\text { to Scale) }\end{array}$ \\
\hline $\begin{array}{l}2014 \\
\text { BAMUIS } \\
\text { BNI }\end{array}$ & 100 & 100 & 100 & 0 \\
\hline $\begin{array}{l}2013 \\
\text { BAMUIS } \\
\text { BNI }\end{array}$ & 100 & 100 & 100 & 0 \\
\hline $\begin{array}{l}2013-\text { BSM } \\
\text { Ummat }\end{array}$ & 100 & 100 & 100 & 0 \\
\hline
\end{tabular}




\begin{tabular}{lllll}
$\begin{array}{l}2012 \\
\text { BAMUIS } \\
\text { BNI }\end{array}$ & 100 & 100 & 100 & 0 \\
\hline $\begin{array}{l}2012-\text { BSM } \\
\text { Ummat }\end{array}$ & 100 & 100 & 100 & 0 \\
\hline $\begin{array}{l}2013 \text { - } \\
\text { YBM BRI }\end{array}$ & 100 & 100 & 100 & 0 \\
\hline $\begin{array}{l}2013- \\
\text { LAZISNU }\end{array}$ & 88,30 & 100 & 88,30 & 0 \\
\hline $\begin{array}{l}2014 \\
\text { YBM BRI }\end{array}$ & 70,30 & 100 & 70,30 & 0 \\
\hline $2012-$ RZ & 33,41 & 100 & 33,41 & 0 \\
\hline $2014-$ RZ & 33,15 & 100 & 33,15 & 0 \\
\hline $\begin{array}{l}2012 \\
\text { BAZNAS }\end{array}$ & 50,26 & 73,46 & 68,42 & 1 \\
\hline $\begin{array}{l}2013 \\
\text { BAZNAS }\end{array}$ & 41,65 & 77,85 & 53,50 & 1 \\
\hline $\begin{array}{l}2012 \\
\text { BMH }\end{array}$ & 37,17 & 76,72 & 48,45 & 1 \\
\hline $\begin{array}{l}2013 \\
\text { BMH }\end{array}$ & 35,07 & 78,68 & 44,57 & 1 \\
\hline $\begin{array}{l}2014 \\
\text { BMH }\end{array}$ & 34,30 & 82,09 & 41,78 & 1 \\
\hline $2013-$ RZ & 28,79 & 97,98 & 29,38 & 1 \\
\hline Rata - Rata & 65,78 & 92,92 & 69,45 & \\
\hline
\end{tabular}

Sumber : Data diolah dari software Banxia Frontier Analyst 3

Berdasarkan tabel 5 terdapat 6 Organisasi Pengelola Zakat (OPZ) dari 16 Decision Making Unit (DMU) yang efisien secara skala dan overall. Adapun secara teknis terdapat 10 Decision Making Unit (DMU) yang sudah mencapai skor efisien. Sisanya lagi yaitu, 6 Decision Making Unit (DMU) memiliki skor di atas 60\%, dan tidak ada Decision Making Unit (DMU) yang memiliki skor di bawah $60 \%$. Hal tersebut menunjukkan bahwa masih ada beberapa Organisasi Pengelola Zakat (OPZ) yang perlu meningkatkan efisiensinya.

Secara umum, kinerja pengelolaan zakat, infak, dan sedekah pada tahun 2013 cenderung lebih efisien dibanding tahun 2012 dan tahun 2014, baik itu secara teknis, skala, maupun overall (lihat grafik 4). Hal ini diantaranya disebabkan karena terjadinya penurunan biaya personalia hingga 13\% di tahun 2013 (lihat tabel 4). Namun sangat disayangkan karena tidak terjadi peningkatan efisiensi pengelolaan zakat, infak, dan sedekah dari tahun 2013 ke tahun 2014. Berikut ini adalah grafik 4 terkait tren efisiensi Organisasi Pengelola Zakat (OPZ). 
Grafik 4. Tren Efisiensi Organisasi Pengelola Zakat Tahun 2012-2014

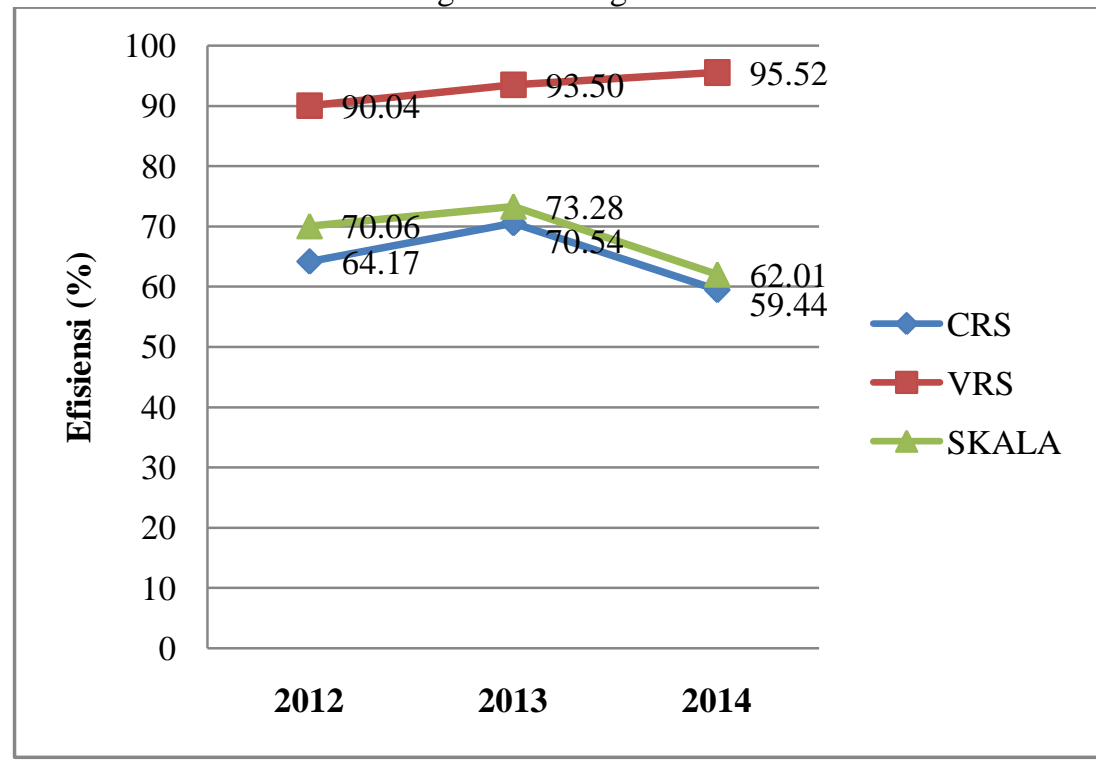

Sumber : Data diolah dari Microsoft Excel 2007

Grafik 4 juga menerangkan bahwa Organisasi Pengelola Zakat (OPZ) cukup efisien secara teknis, yakni 90,04\% pada tahun 2012, 93,50\% pada tahun 2013, dan 95,52\% pada tahun 2014. Namun, masih kurang efisien secara skala. Kecenderungan tingginya efisiensi teknis dibanding efisiensi skala menunjukkan bahwa kinerja amilin Organisasi Pengelola Zakat (OPZ) sudah cukup baik dalam menghimpun dana zakat, infak, dan sedekah serta menyalurkannya dengan input yang dimiliki, tetapi masih kurang mendapat dukungan dari kondisi eksternal (di luar manajemen). Kemudian rendahnya efisiensi skala berdampak pada rendahnya efisiensi secara overall.

Hasil pengolahan menunjukkan bahwa 6 Decision Making Unit (DMU) berada dalam kondisi Increasing Return to Scale (IRS) yang dinotasikan dengan angka 1, dan tidak ada Decision Making Unit (DMU) yang mengalami kondisi Decreasing Return to Scale (DRS) yang dinotasikan dengan angka -1 (lihat tabel 5). Kondisi Increasing Return to Scale (IRS) memungkinkan untuk terus meningkatkan kapasitas outputnya dengan mempertahankan input yang ada, karena penambahan input justru tidak efektif mengingat sumber daya yang digunakan masih belum berfungsi secara optimal. Adapun kondisi Decreasing Return to Scale (DRS) menuntut adanya penggunaan input, karena jumlah input sudah tidak ideal.

\subsection{PERBANDINGAN EFISIENSI ANTAR ORGANISASI PENGELOLA ZAKAT}

Berdasarkan pengolahan terhadap laporan keuangan dari 7 Organisasi Pengelola Zakat (OPZ) dengan variasi tahun berbeda, dapat diketahui Organisasi Pengelola Zakat (OPZ) yang paling efisien dan inefisien. 
Perhitungan secara teknis menunjukkan bahwa BAMUIS BNI, BSM Ummat, dan YBM BRI merupakan Organisasi Pengelola Zakat (OPZ) yang paling efisien dari tahun ke tahun, yakni 100\% sepanjang tahun 2012 sampai dengan tahun 2014 bagi BAMUIS BNI, 100\% sepanjang tahun 2012 sampai dengan tahun 2013 bagi BSM Ummat, dan 100\% sepanjang tahun 2013 sampai dengan tahun 2014 bagi YBM BRI (lihat grafik 5). Adapun LAZISNU belum cukup untuk dikatakan sebagai Organisasi Pengelola Zakat (OPZ) terbaik dikarenakan tidak adanya data yang lengkap dari tahun ke tahun yang diperoleh penulis. Berikut ini adalah grafik 5 yang menggambarkan perbandingan efisiensi teknis.

Grafik 5. Perbandingan Efisiensi Teknis

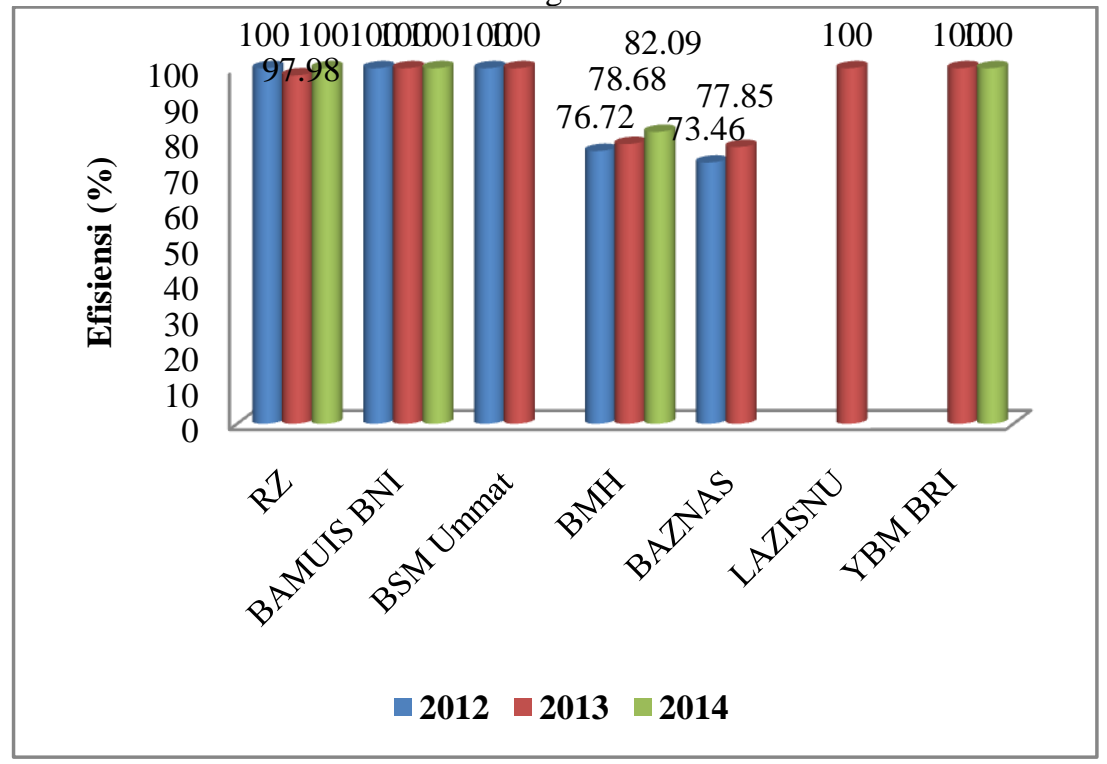

Sumber : Data diolah

Faktor yang mempengaruhi inefisiensi secara teknis adalah kurang maksimalnya penggunaan kapasitas input. Hal ini diketahui dari 6 nilai Return to Scale (RTS) yang menunjukkan angka 1 atau menggambarkan kondisi Increasing Return to Scale (IRS) (lihat tabel 5). Sedangkan pada tabel 5 tersebut tidak ada Organisasi Pengelola Zakat (OPZ) yang mengalami kondisi Decreasing Return to Scale (DRS) atau -1, dimana penambahan input tidak dapat menambah output yang sama besarnya atau lebih besar. Oleh karena itu, apabila terdapat Organisasi Pengelola Zakat (OPZ) yang mengalami kondisi Decreasing Return to Scale (DRS), maka diperlukan pengurangan input hingga mencapai titik Constant Return to Scale (CRS).

Adapun perhitungan secara skala menunjukkan bahwa Organisasi Pengelola Zakat (OPZ) yang paling efisien adalah BAMUIS BNI dan BSM Ummat, yakni 100\% sepanjang tahun 2012 sampai dengan tahun 2014 bagi BAMUIS BNI, dan 100\% sepanjang tahun 2012 sampai dengan tahun 2013 
bagi BSM Ummat (lihat grafik 6). Keduanya adalah Organisasi Pengelola Zakat (OPZ) yang beroperasi di dalam lingkungan perusahaan atau lembaga bisnis perkantoran. Hal ini memberikan keuntungan efisiensi skala dibanding Organisasi Pengelola Zakat (OPZ) lain, karena dengan input minimal dapat menghasilkan output yang lebih besar. Seperti contohnya BAMUIS BNI yang melakukan pemotongan $2,5 \%$ dari gaji para karyawannya setiap bulan, bila pendapatannya mencapai $94 \%$ gram emas dalam setahun. Mekanisme ini tentunya dapat menghemat penggunaan input, salah satunya dengan menghemat biaya sosialisasi. Berikut ini adalah grafik 6 yang menggambarkan perbandingan efisiensi skala.

Grafik 6. Perbandingan Efisiensi Skala

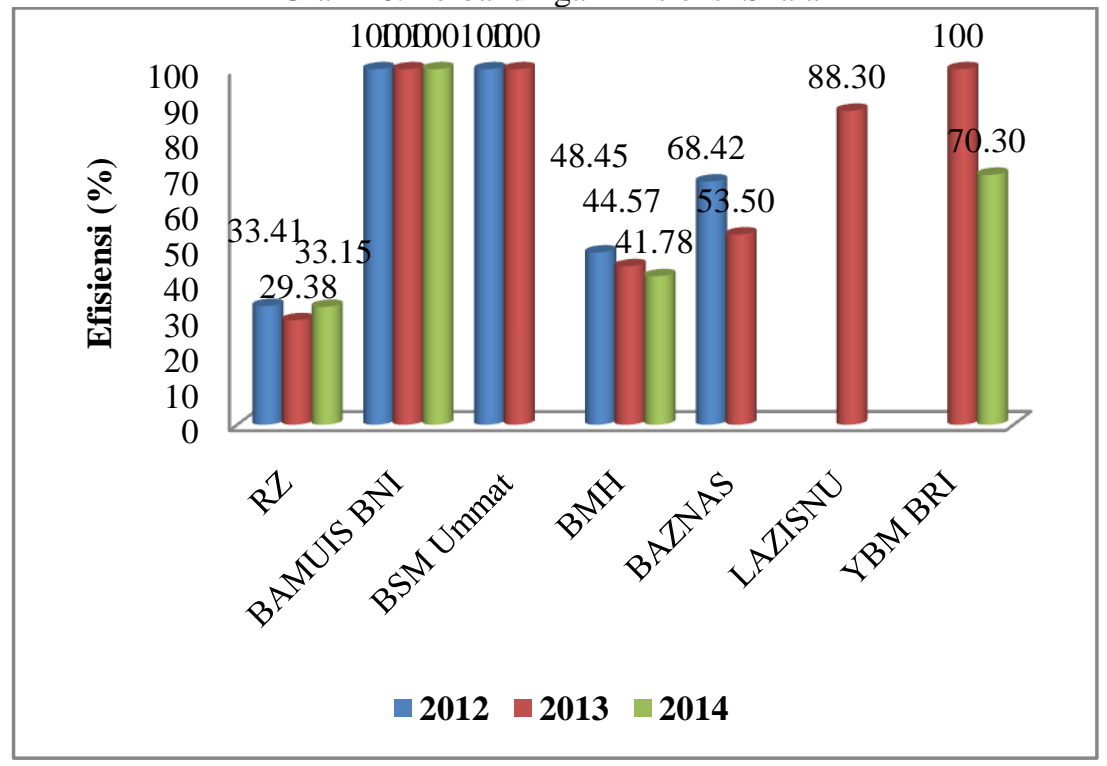

Sumber : Data diolah

Sementara itu, grafik 6 menunjukkan tingkat efisiensi 7 Organisasi Pengelola Zakat (OPZ) secara overall. Tampak bahwa BAMUIS BNI dan BSM Ummat adalah Organisasi Pengelola Zakat (OPZ) yang paling efisien diantara 5 Organisasi Pengelola Zakat (OPZ) lainnya, yakni 100\% sepanjang tahun 2012 sampai dengan tahun 2014 bagi BAMUIS BNI, dan 100\% sepanjang tahun 2012 sampai dengan tahun 2013 bagi BSM Ummat. Tingginya angka overall menunjukkan bahwa kedua Organisasi Pengelola Zakat (OPZ) ini sangat efisien baik secara teknis maupun skala. Oleh karena itu, kedua Organisasi Pengelola Zakat (OPZ) ini dapat dijadikan benchmark bagi 5 Organisasi Pengelola Zakat (OPZ) lainnya. Berikut ini adalah grafik 7 yang menggambarkan perbandingan efisiensi overall. 
Grafik 7. Perbandingan Efisiensi Overall

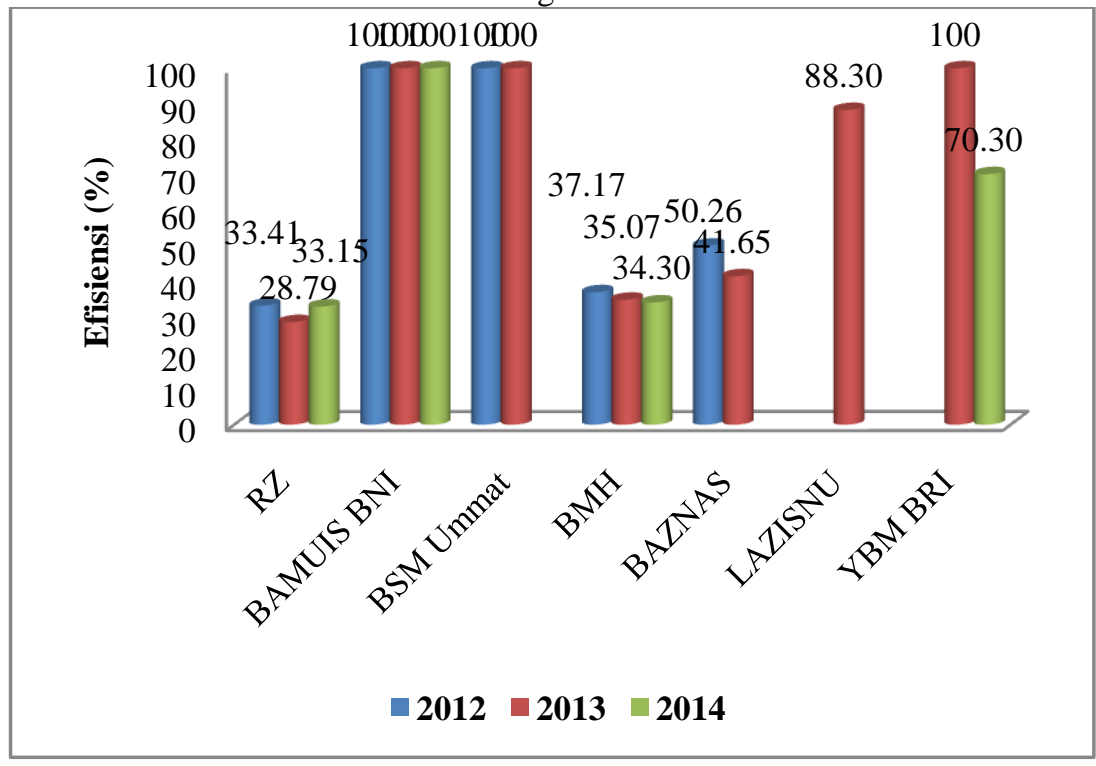

Sumber : Data diolah

\section{SIMPULAN}

Berdasarkan hasil penelitian, diketahui bahwa kinerja Organisasi Pengelola Zakat (OPZ) pada tahun 2013 lebih efisien dari tahun 2012 dan tahun 2014. Hal ini diantaranya disebabkan karena terjadinya penurunan biaya personalia hingga $13 \%$ di tahun 2013. Namun sangat disayangkan karena tidak terjadi peningkatan efisiensi pengelolaan zakat, infak, dan sedekah dari tahun 2013 ke tahun 2014.

Kinerja Organisasi Pengelola Zakat (OPZ) sudah cukup efisien secara teknis, yakni $90,04 \%$ pada tahun $2012,93,50 \%$ pada tahun 2013 , dan $95,52 \%$ pada tahun 2014. Hal ini menjelaskan bahwa Organisasi Pengelola Zakat (OPZ) telah memiliki manajemen yang baik dalam mengoptimalkan penggunaan input untuk menghimpun dan menyalurkan dana zakat, infak, dan sedekah. Meski demikian, hal ini tidak didukung oleh kondisi eksternal yang baik. Terbukti dengan rendahnya tingkat efisiensi secara skala yang juga berpengaruh terhadap rendahnya nilai efisiensi secara overall.

Perhitungan secara overall menginformasikan bahwa 6 dari 16 Decision Making Unit (DMU) berada pada titik efisien atau mencapai skor 100\%. Sisanya lagi yaitu, 3 dari 16 Decision Making Unit (DMU) berada pada skor diantara 50\%-99\%, dan 7 dari 16 Decision Making Unit (DMU) berada pada skor diantara 0\%-49\%. Perhitungan secara teknis menginformasikan bahwa 10 dari 16 Decision Making Unit (DMU) berada pada titik efisien atau mencapai skor $100 \%$. Sisanya lagi yaitu, 6 dari 16 
Decision Making Unit (DMU) berada pada skor diantara 50\%-99\%, dan tidak ada Decision Making Unit (DMU) yang berada pada skor diantara 0\%-49\%. Perhitungan secara skala menginformasikan bahwa 6 dari 16 Decision Making Unit (DMU) berada pada titik efisien atau mencapai skor $100 \%$. Sisanya lagi yaitu, 4 dari 16 Decision Making Unit (DMU) berada pada skor diantara 50\%-99\%, dan 6 dari 16 Decision Making Unit (DMU) berada pada skor diantara $0 \%-49 \%$.

Organisasi Pengelola Zakat yang beroperasi di lingkungan perusahaan atau lembaga bisnis perkantoran (perbankan) cenderung lebih efisien dibandingkan dengan Organisasi Pengelola Zakat selain perbankan, seperti BAMUIS BNI, BSM Ummat, dan YBM BRI. Hal ini dikarenakan tingkat kemudahan Organisasi Pengelola Zakat (OPZ) perbankan dalam melakukan penghimpunan dana zakat, infak, dan sedekah dengan adanya sistem pemotongan gaji para karyawan bank tersebut.

Perhitungan terhadap 7 Organisasi Pengelola Zakat (OPZ) tahun 2013 dengan asumsi Constant Return to Scale (CRS) dengan menggunakan pengukuran orientasi input dan output menunjukkan hanya 3 Organisasi Pengelola Zakat (OPZ) yang efisien, yaitu BAMUIS BNI, BSM Ummat, dan YBM BRI. Dan Organisasi Pengelola Zakat (OPZ) yang paling banyak dijadikan benchmark adalah YBM BRI.

\section{DAFTAR PUSTAKA}

Beik, I. S., \& Tanjung, H. (2011). Indonesia Zakat \& Development Report 2011, Kajian Empiris Peran Zakat Dalam Pengentasan Kemiskinan. Ciputat: Indonesia Magnificence of Zakat.

Hansen, D. R., \& Mowen, M. M. (2001). Manajemen Biaya: Akuntansi Dan Pengendalian Buku 2. Jakarta: Salemba Empat.

Karim, A. (2011). Ekonomi Mikro Islam. Jakarta: PT. Raja Grafindo Persada.

Majelis Ulama Indonesia. (2011). Himpunan Fatwa Zakat MUI. Jakarta: Majelis Ulama Indonesia.

Mardiasmo. (2009). Akuntansi Sektor Publik. Yogyakarta: CV. Andi Offset.

Mintarti, N., \& Beik, I. S. (2012). Indonesia Zakat \& Development Report 2012. Ciputat: Indonesia Magnificence of Zakat.

Nasution, M. E., \& Mintarti, N. (2009). Indonesia Zakat \& Development Report 2009, Zakat Dan Pembangunan: Era Baru Zakat Menuju Kesejahteraan Ummat. Ciputat: Indonesia Magnificence of Zakat.

Nordiawan, D., \& Hertianti, A. (2010). Akuntansi Sektor Publik. Jakarta: Salemba Empat.

Qardhawi, Y. (2007). Hukum Zakat. Jakarta: Litera Antar Nusa.

Qardhawi, Y. (2005). Spektrum Zakat. Jakarta: Zikrul Hakim. 
Tanjung, H., \& Devi, A. (2013). Metodologi Penelitian Ekonomi Islam. Jakarta: Gramata Publishing.

Undang-Undang. (2011). Undang-Undang Republik Indonesia Nomor 23 Tahun 2011 Tentang Pengelolaan Zakat. Jakarta: Republik Indonesia.

BAZNAS. (2015). Badan Amil Zakat Nasional (BAZNAS). Dipetik November 14, 2015, dari www.baznas.go.id: http://pusat.baznas.go.id/

Indonesia Investments. (2015, Oktober 30). Kemiskinan Di Indonesia. Dipetik November 01, 2015, dari www.indonesia-investments.com: http://www.indonesia-investments.com/id/keuangan/angka-ekonomimakro/kemiskinan/item301

Republika Online. (2015). Potensi Zakat Besar Tapi.. Jakarta: ROL Republika Onlin 